\title{
LOW INTENSITY LASER EFFECTS ON FACTORS OF CONGENITAL IMMUNITY AND CYTOKINE BALANCE IN SECRETIONS OF FEMALE REPRODUCTIVE SYSTEM AFFECTED WITH CHLAMYDIA INFECTION
}

\section{O.A. Gizinger}

Dr. Sci. (Biol.), Prof., Leading Researcher State Research Center for Laser Medicine after O.K. Skobelkina of the Federal Medical Biological Agency 17 Pokrovskaya St., korp. 1, ap. 120, Moscow, Russia tel.: +7 (919) 319-46-04

e-mail: OGizinger@gmail.com ORCID 0000-0001-9302-0155

\author{
V.I. Karandashov \\ Dr. Sci. (Med.), Prof., Director of department \\ Department of Laser Biotechnol. and Clinical Pharmacol. \\ State Research Center for Laser Medicine after \\ O.K. Skobelkina of the Federal Medical Biological Agency \\ 40 Studencheskaya St., Moscow, 121165, Russia \\ tel.: +7 (916) 397-40-88 \\ e-mail:kvi42@list.ru \\ ORCID 0000-0002-0026-8862
}

Introduction. Chlamydia infection is one of the most widespread sexually transmitted diseases. The efficiency of its treatment largely depends on the condition of the factors of the local anti-infective protection of the reproductive tract, so studying the immune reactions at the local level, i.e. directly in the affected area, may be an important field in searching for pathogenetic therapy.

Therefore, we defined the objective of our research: to study the factors of uterine cervix tissue immunity for women with Chlamydia infection and to estimate the effect of low-intensity laser therapy (LILT) on these factors due to a wavelength of $632 \mathrm{~nm}$ and a power of $30 \mathrm{~mW}$.

Materials and methods. Clinical immunologic studies of cervical secretion were carried out on 184 women of reproductive age 25,9 4,22 in 2016-2018. Chlamydia infection Chlamydia trachomatis was found by the methods of real-time polymerase chain reaction (Rt-PCR) tests. Code by Classifier of the International Standard Classification of Diseases and Related Health Problems 10th Revision is A 56.0, Chlamydial infections of the lower sections of the urogenital tract. Urethra and canalis cervicis uteri scrapings were used as the material for detecting C. trachomatis. All patients with chlamydial infection of the lower part of the urogenital system were divided into two groups: a group of 100 women who were treated by using the local influence of the low-intensity laser of $632 \mathrm{~nm}$ as a part of complex treatment, the comparison group (basic treatment) consisted of 84 women who took azithromycin of $1 \mathrm{~g}$ once a day for the 1st, 5th, 10th days of treatment. 50 healthy women without any pathology and infections of the genitourinary system made the control group. A system of cytokines was studied by interleukin's level IL-8. IL- $1 \alpha$, IL- $1 \beta$, TNF- $\alpha$ and IFN- $\gamma$ content in cervical mucus.

Results Course. The results of the study showed a high clinical and immunological efficacy of treating chlamydial cervicitis using a low intensity laser with a wavelength of $632 \mathrm{~nm}$. An imbalance of cellular factors of innate immunity revealed before starting a therapy: a decrease in the oxygen-dependent metabolism of neutrophilic granulocytes of the cervical secretion

Key words: laser radiation, Chlamydia trachomatis, neutrophilic granulocyte, immunity, cytokine.

\section{ВПЛИВ НИЗЬКОІНТЕНСИВНОГО ЛАЗЕРНОГО ВИПРОМІНЮВАННЯ НА ФАКТОРИ ВРОДЖЕНОГО ІМУНІТЕТУ ТА БАЛАНС ЦИТОКІНІВ У СЕКРЕТІ РЕПРОДУКТИВНОЇ СИСТЕМИ ЖІНОК ІЗ ХЛАМІДІЙНОЮ ІНФЕКЦІЄЮ}

\section{О.А. Гізінгер, В.І. Карандашов}

Державний науковий центр лазерної медицини ім. О.К. Скобелкіна ФМБА, м. Москва, Росія

Вступ. Хламідійна інфекція $\epsilon$ одним з найбільш поширених захворювань, що передаються статевим шляхом. Ефективність його лікування багато в чому залежить від стану факторів місцевої протиінфекційного захисту репродуктивного тракту, тому вивчення імунних реакцій на місцевому рівні, тобто безпосередньо в зоні ураження, може стати важливою областю при пошуку патогенетичної терапії.

Мета дослідження - вивчити фактори місцевого імунітету шийки матки у жінок із хламідійною інфекцією та оцінити локальний вплив низькоінтенсивного лазерного випромінювання (НІЛВ) 3 довжиною хвилі 632 нм, потужністю випромінювання 30 мВт на ці фактори.

Матеріали та методи. У дослідженнях взяли участь 184 жінки репродуктивного віку 25,9 4 4,22, у яких Chlamydia trachomatis була виявлена методом полімеразної ланцюгової реакції. Код класифікатора за МКБ-10: А56.0 - Хламідійні інфекції нижніх відділів сечостатевого тракту. Матеріалом для виявлення C. trachomatis були епітеліальні клітини, отримані шляхом зіскрібків з уретри і цервікального каналу. Система цитокінів вивчена на вміст інтерлейкінів-8, $1 \alpha, 1 \beta$, фактора некрозу пухлини $\alpha$, інтерферону-ү. 
Пацієнти з хламідійною інфекцією нижнього відділу сечостатевої системи були розділені на дві групи: група з 100 жінок, яких лікували з використанням локального впливу лазера низької інтенсивності, група порівняння (базисна терапія) складалася з 84 жінок, які отримували азитроміцин по 1 г один раз в день на 1-й, 5-й, 10-й день лікування. Групу контролю склали 50 здорових жінок без патології та інфекцій сечостатевої системи.

Результати дослідження показали високу клініко-імунологічну ефективність лікування хламідійного цервіциту з використанням лазера низької інтенсивності з довжиною хвилі 632 нм, виражену у відновленні кисневозалежного метаболізму фагоцитів цервікального секрету.

Ключові слова: лазерне випромінювання, Chlamydia trachomatis, нейтрофільний гранулоцит, імунітет, цитокіни.

\section{ВЛИЯНИЕ НИЗКОИНТЕНСИВНОГО ЛАЗЕРНОГО ИЗЛУЧЕНИЯ НА ФАКТОРЫ ВРОЖДЕННОГО ИММУНИТЕТА И БАЛАНС ЦИТОКИНОВ В СЕКРЕТАХ РЕПРОДУКТИВНОЙ СИСТЕМЫ ЖЕНЩИН С ХЛАМИДИЙНОЙ ИНФЕКЦИЕЙ}

\section{О.А. Гизингер, В.И. Карандашов}

Государственный научный центр лазерной медицины им. О.К. Скобелкина ФМБА, г. Москва, Россия

Введение. Хламидийная инфекция является одним из наиболее распространенных заболеваний, передаваемых половым путем. Әффективность его лечения во многом зависит от состояния факторов местной противоинфекционной защиты репродуктивного тракта, поэтому изучение иммунных реакций на местном уровне, то есть непосредственно в зоне поражения, может стать важной областью при поиске патогенетической терапии.

Цель исследования - изучить факторы местного иммунитета шейки матки у женщин с хламидийной инфекцией и оценить локальное влияние низкоинтенсивного лазерного излучения (НИЛИ) с длиной волны 632 нм, мощностью излучения 30 мВт на эти факторы.

Материалы и методы. В исследование включены 184 женщины репродуктивного возраста $25,9 \pm 4,22$, у которых Chlamydia trachomatis была обнаружена методом полимеразной цепной реакции. Код классификатора по МКБ-10: А56.0 - Хламидийные инфекции нижних отделов мочеполового тракта. В качестве материала для выявления C. trachomatis были эпителиальные клетки, полученные путем соскобов с уретры и цервикального канала. Система цитокинов изучена по содержанию интерлейкинов-8, $1 \alpha, 1 \beta$, фактора некроза опухоли $\alpha$, интерферона- $\gamma$. Пациенты с хламидийной инфекцией нижнего отдела мочеполовой системы были разделены на две группы: группа из 100 женщин, которых лечили с использованием локального воздействия лазерным излучением низкой интенсивности. Группа сравнения (базисная терапия) состояла из 84 женщин, которые получали азитромицин по 1 г один раз в день на 1-й, 5-й, 10-й день лечения. Группу контроля составили 50 здоровых женщин без патологии и инфекций мочеполовой системы.

Результаты исследования показали высокую клинико-иммунологическую эффективность лечения хламидийного цервицита с использованием лазерного излучения низкой интенсивности с длиной волны 632 нм, выраженную в восстановлении кислородзависимого метаболизма фагоцитов цервикального секрета.

Ключевые слова: низкоинтенсивное лазерное излучение, Chlamydia trachomatis, нейтрофильный гранулоцит, иммунитет, цитокин.

\section{Introduction}

Chlamydia infection is one of the most widespread sexually transmitted diseases [1]. The efficiency of its treatment largely depends on the condition of the factors of the local anti-infective protection of the reproductive tract, so studying the immune reactions at the local level, i.e. directly in the affected area, may be an important field in searching for pathogenetic therapy and it stipulates the search for the ways of therapeutic modality onto the patient's organism both at the system and local level [2]. Local administration of immune correction can be a promising trend in this field, and a low-intensity laser may be one of them [3]. It is known as a highly efficient therapeutic agent, and the data in the recent studies on the complex effect of low-intensity laser radiation on all elements of immune pathology at the local and system levels are available.

The aim of the study was to define the objective of our research: to characterize the factors of cervical secretion tissue immunity for women with Chlamydia infection and to estimate the effect of low-intensity laser radiation (radiation power $-30 \mathrm{~mW}$, wavelength $-632 \mathrm{~nm}$ ) upon these factors.

\section{Materials and methods}

Clinical immunologic studies of cervical secretion were carried out on 184 women of reproductive age 25,90 \pm 4,22 in 2016-2018. Chlamydia infection Chlamydia trachomatis was found by the methods of polymerase chain reaction [4]. Code by Classifier of the International Standard Classification of Dis- 
eases and Related Health Problems 10th Revision is A 56.0, Chlamydial infections of the lower sections of the urinary tract. Urethra and canalis cervicis uteri scrapings were used as the material for detecting C. trachomatis. All patients of the first group with chlamydial infection of the lower part of the urogenital system were divided into two groups: a group of 100 women who were treated by using the local influence of the low-intensity laser of $632 \mathrm{~nm}$ as a part of complex treatment, the comparison group consisted of 84 women who took azithromycin of $1 \mathrm{~g}$ once a day for the $1 \mathrm{st}, 5 \mathrm{th}, 10 \mathrm{th}$ days of treatment. 50 healthy women without any pathology and infections of the genitourinary system made the control group. The criterion for being in the studied group was presence of Chlamydia cervicitis. Cervicitis was registered in $99,50 \%$ of patients with Chlamydia infection endometriosis and/or salpingo-oophoritis in $29,60 \%$ of them. Women with extra genital pathology were excluded from the studied group as any pathological process significantly affects the immunity. All patients were at the stage of clinical laboratory remission of the upper genitalia at the moment of examination. Cervical secretion was the studied material of a reproductive tract tissue immunity because experimental clinical study identifies body fluids, in our case cervical secretion, as elements of the body receptor system, the medium that enhances and memorizes weak external effects. Structural changes in micellar and other solutions of bimolecular and also in native body fluids represent a possible cause of non-specific reaction of the enhanced activity of biochemical processes affected by LILT [5]. We studied cellular content of cervical secretion, the number of neutrophiles, mononuclears, percentage of viable cells. Functional status of neutrophiles in the secretion was defined by the lisosome content, on the basis of instant NBT-regeneration ability induced by latex and phagocyte activity [6]. Cytokine system was studied via interleukin content $1 \alpha, 1 \beta, 8$ (IL-1 $\alpha$, IL-1 $\beta$, IL-8), factors of tumor necroses $\alpha-$ FTN $\alpha$ and interferon $\gamma(\mathrm{IFN}-\gamma)$ in cervical secretion were studied by Enzyme-linked immunosorbent assay (ELISA). The results were processed by variation statistics and MFE and its standard error $(\mathrm{M} \pm \mathrm{m})$ were calculated. Statistic hypothesis of Gaussian distribution by $\chi^{2}$ and Kolmogorov-Smirnov criteria of dispersion equality were checked for each index. In case of Gaussian distribution the certainty of deviation of the mean values was estimated by Student's t-criterion. When the conditions of Gaussian distribution were not observed we applied a Mann-Whitney non-parametric criterion. Statistical processing of the results of the study was carried out using the software «Statistica 10». Digital data were processed by variation statistics methods with the help of Statistics for Windows software package. Helium neon laser working in continuous radiation mode was used as the main source of laser radiation. The patients were treated with «Mustang-2000» device for laser treatment of biological objects in clinical medicine. Laser treatment was carried out patiently in a specially equipped room. The patient was placed on the bed with an elevated pelvis area and lay on the back with the bent knees. Continuous mode of radiation was used, a wave- length was $632 \mathrm{~nm}$, an average emissive power was $30 \mathrm{~mW}$. The method of administering was intra vaginal. Hollow nozzle placed in a sheath was used. The exposure lasted 10 min., the course of treatment included 10 manipulations.

\section{Results Course}

In the patient group that had a low-intensity laser treatment included in their therapy clinical recovery and complete eradication of Chlamydia were observed in $98.1 \%$ of women, while patients treated under the basic scheme clinically recovered in $91 \%$ of cases. Positive clinical results of laser treated patients were significantly higher than those who received a basic treatment. Estimating the immune status of the patients received the complex treatment that included LILT showed a clear tendency of normalizing the indices of female reproductive tract tissue immunity. Low-intensity laser impact on the main effector functions of the cervical secretion neutrophils in females suffering from Chlamydia infection has been studied. Total number of leucocytes dramatically deceased in the cervical secretion of the patients after a low-intensity laser treatment. After the basic scheme treatment the significant decrease of leucocytes was also noted, but the normalization degree of leucocyte content in cervical secretion was less evident. The number of viable leucocytes dramatically decreased after the course of a laser treatment as compared to the initial level as well as to the results of the patients treated under the basic scheme. Decreasing the number of viable leucocytes was also noted after the basic treatment, this dynamics was less evident. Neutrophils content in body fluids is an important indicator of inflammation in the reproductive tract. It is not much in the cervical secretion of intact women though comparable to their content in blood [7], but it increases with inflammation. Thus, neutrophiles were $95.5 \%$ of the total number of cells in the patients with Chlamydia cervitis. After the treatment with LILT their number was $98.1 \%$ and it was $99.2 \%$ of the total cell number after the basic treatment. Content of mononuclear leucocytes was $5.5 \%$ in the patients with Chlamydia cervitis and decreased both after a therapy with LILT and a basic scheme therapy. A number of leucocytes in the cervical secretion and data on leucocyte viability can be an index of inflammation for the patients with Chlamydia cervitis and can be used in estimating the efficiency of the effected therapy (Table 1).

Leucocytes in cervical secretion are mostly neutrophiles that play an important role in protecting the reproductive tract from infection [8] and are an important component of the non-specific element of the 
immune system, so we studied their functional activity in detail. We studied phagocyte activity of neutrophiles in the cervical secretion due to their ability to absorb the latex microspheres and found that the patients with Chlamydia cervitis had much lower activity and intensity of phagocytes and statistically they were significantly different from the results of the intact women $(\mathrm{p}<0,005)$. After the LILT therapy positive dynamics and recovery of these indices were noted, while though a tendency towards improving was observed, it was not so significant. We studied the lissome activity of neutrophiles in the cervical secretion in intact women and women with Chlamydia cervitis. The studies showed the decrease of this index in the women with Chlamydia cervitis $(p>0.005)$. The immunological effect of LILT as compared to the traditional methods of treatment involves the dramatic increase of lissome activity in cervical secretion. It was noted during the analysis of data on NBT regeneration ability in cervical secretion that the patients with Chlamydia cervitis had

\section{Immunological indices of cervical secretion in patients with Chlamydia cervitis before and after treatment $(M \pm m)$}

\begin{tabular}{|c|c|c|c|c|c|}
\hline \multirow{3}{*}{ Index } & \multirow[b]{2}{*}{ Intact $(n=50)$} & \multicolumn{3}{|c|}{ Infected with Chlamidia cervicitis } & \multirow{3}{*}{$\mathrm{p}<0.005$} \\
\hline & & $\begin{array}{c}\text { Before } \\
\text { treatment } \\
(n=184)\end{array}$ & $\begin{array}{c}\text { After laser } \\
\text { treatment } \\
(n=100) \\
\end{array}$ & $\begin{array}{c}\text { After basic } \\
\text { treatment } \\
(\mathrm{n}=84)\end{array}$ & \\
\hline & 1 & 2 & 3 & 4 & \\
\hline Leucocytes $10^{9} / \mathrm{I}$ & $7,06 \pm 0,68$ & $7,53 \pm 0,71$ & $7,16 \pm 0,91$ & $7,36 \pm 1,13$ & $1-2,4 ; 2-3,4 ; 3-4$ \\
\hline Viable leucocytes, \% & $62,09 \pm 1,35$ & $68,20 \pm 1,51$ & $61,45 \pm 1,23$ & $63,69 \pm 1,78$ & $1-2,4 ; 2-3,4 ; 3-4$ \\
\hline Neutrophiles, \% & $93,23 \pm 1,2$ & $95,53 \pm 0,96$ & $98,5 \pm 1,11$ & $99,26 \pm 0,77$ & $1-2,4 ; 2-3,4$ \\
\hline Mononuclears, \% & $6,84 \pm 0,91$ & $4,54 \pm 0,77$ & $1,55 \pm 0,32$ & $0,85 \pm 0,12$ & $1-2,4 ; 2-3,4$ \\
\hline $\begin{array}{l}\text { Lysosome activity } \\
\text { neutrophiles, \% }\end{array}$ & $25,17 \pm 0,95$ & $20,19 \pm 1,73$ & $29,95 \pm 1,23$ & $21,19 \pm 1,52$ & $1-2,4 ; 2-3,4 ; 3-4$ \\
\hline $\begin{array}{l}\text { NBT instant } \\
\text { neutrophiles, \% }\end{array}$ & $29,83 \pm 0,97$ & $45,61 \pm 0,95$ & $50,91 \pm 0,95$ & $35,61 \pm 0,95$ & $1-2,4 ; 2-3,4 ; 3-4$ \\
\hline NBT instant, RVU & $0,35 \pm 0,01$ & $0,65 \pm 0,02$ & $0,73 \pm 0,06$ & $0,59 \pm 0,03$ & $1-2,4 ; 2-3,4 ; 3-4$ \\
\hline $\begin{array}{l}\text { NBT induced } \\
\text { monocytes, \% }\end{array}$ & $57,11 \pm 0,82$ & $60,39 \pm 0,97$ & $89,32 \pm 0,27$ & $55,30 \pm 0,90$ & $1-2,4 ; 2-3,4 ; 3-4$ \\
\hline $\begin{array}{l}\text { NBT induced } \\
\text { monocytes, RVU }\end{array}$ & $0,69 \pm 0,02$ & $0,83 \pm 0,01$ & $0,99 \pm 0,11$ & $0,63 \pm 0,002$ & $1-2,4 ; 2-3,4 ; 3-4$ \\
\hline FRN, \% & $1,91 \pm 0,04$ & $1,38 \pm 0,22$ & $1,78 \pm 0,15$ & $1,57+0,11$ & $1-2,4 ; 2-3,4 ; 3-4$ \\
\hline $\begin{array}{l}\text { Phagocyte } \\
\text { activity, \% }\end{array}$ & $55,37 \pm 1,02$ & $45,65 \pm 0,77$ & $55,21 \pm 1,16$ & $47,63 \pm 0,9$ & $1-2,4 ; 2-3 ; 3-4$ \\
\hline
\end{tabular}

Note. Only significant differences between the groups are included in the Table; $p_{1-2 ;} p_{1-3 ;}$ p1-4 - significance with regard to the intact women is p1-2, 2-3, 3-4-probable error is calculated between the relevant groups, FRN stands for functional reserve of neutrophiles. NBT means nitrobule tetrazolium test.

\section{Cytokine level $(\mathrm{pg} / \mathrm{ml})$ in cervical secretion in patients with Chlamydia cervitis} before and after treatment $(M \pm m)$

\begin{tabular}{|c|c|c|c|c|c|}
\hline \multirow{3}{*}{ Index } & \multirow[b]{2}{*}{ Intact $(n=50)$} & \multicolumn{3}{|c|}{ Infected with Chlamidia cervitis } & \multirow{3}{*}{$\mathrm{p}<0.005$} \\
\hline & & $\begin{array}{c}\text { Before } \\
\text { treatment }(n=184)\end{array}$ & $\begin{array}{c}\text { After laser } \\
\text { treatment }(n=100)\end{array}$ & $\begin{array}{c}\text { After basic } \\
\text { treatment }(n=84)\end{array}$ & \\
\hline & 1 & 2 & 3 & 4 & \\
\hline IL-1 $\alpha$ & $3,32 \pm 0,36$ & $2,37 \pm 0,15$ & $3,1 \pm 0,91$ & $2,57 \pm 0,04$ & $1-4 ; 2-3,4 ; 3-4$ \\
\hline IL-1 $\beta$ & $2,11 \pm 0,35$ & $1,26 \pm 0,18$ & $2,05 \pm 0,03$ & $1,39 \pm 0,03$ & $1-4 ; 2-3,4 ; 3-4$ \\
\hline TNF- $\alpha$ & $2,87 \pm 0,44$ & $2,47 \pm 0,45$ & $2,95 \pm 0,11$ & $2,56 \pm 0,14$ & $1-4 ; 2-3,4$ \\
\hline IL-8 & $0,45 \pm 0,12$ & $1,01 \pm 0,1$ & $0,5 \pm 0,16$ & $0,83 \pm 0,03$ & $1-4 ; 2-3,4$ \\
\hline IFN-Y & $0,032 \pm 0,02$ & $0,018 \pm 0,07$ & $0,028 \pm 0,02$ & $0,020 \pm 0,01$ & $1-4 ; 2-3$ \\
\hline
\end{tabular}

Note. Only significant differences between the groups are included in the Table.; $p_{1-2 ;} p_{1-3 ;} p_{1-4}$ - significance with regard to the intact women is p1-2, 2-3, 3-4 - probable error is calculated between the relevant groups, IL - interleukin. 
an increased number of such cells as compared to those ones that intact patients had.

The study of NBT reaction of neutrophiles in the secretion for the added latex particles did not show any distortions in the ability of these cells to regenerate in the intact women. Simultaneously we studied the effect of laser radiation on the activity of PML in cervical secretion. One of the earliest and universal features of the activated phagocyte cells is "respiratory burst" estimated with the test for NBT regeneration. Laser radiation of neutrophile leucocytes in vitro led to the dramatic increase in the values of NBT test. The NBT-test is a technique particularly used in its stimulated variant for testing granulocyte metabolism and in this capacity it is an integrated part of the test programme for differentiating neutrophilic dysfunctions [9]. This index increases due to the increased number of granulas of regenerated formazan in cell cytoplasm, resulting in higher percentage of neutrophiles completely filled with the granulas as well as the total number of the formazanized cells. It may be supposed that it is linked with the stimulation of the ferments hexomonophosphate shunt, particularly NADPH oxidase, glucose-6-phosphatehydrogenase or other enzymes responsible for NBT reduction [10]. This can also be the evidence of the changed functional activity of the phagocyte membranes effected by LILT [11].

The functional reserve of neutrophiles in the infected women was much lower than that of the intact ones. Regeneration of this index in the group of women treated without a laser was much slower and there was no complete normalization of this cell function by the end of the treatment.

The data on the clinical immunological observation of patients with Chlamydia cervitis show matching between clinical progress notes and normalization of immunological indices. We suppose that as the body gets rid of the pathogene, more possibilities for activating the system of tissue immunity appear in the reproductive tract. Our results make it possible to see a low-intensity laser therapy as a method to increase non-specific resistance of the reproductive tract. We analyzed the influence of a laser therapy on the condition of cytokine system in women infected with Chlamydia cervitis (Table 2).

Analysis of the examination results before treatment showed that taking into account the studied inflammation mediators in cervical secretion the content of IL-8, concentrations of IL- $1 \alpha$, IL- $1 \beta$ and FTN- $\alpha$ increased while IFN- $\gamma$ remained significantly lower as compared to the indices of the intact women. The level of anti-inflammation cytokines in the secretion increased in women with Chlamydia cervitis in the process of LILT treatment and it corresponded to that of the intact women by the end of the treatment. These cytokines are mediators of the local inflammatory reaction and acute phase response at the level of both the body as a whole and a reproductive tract in particular.
They stimulate the whole set of protective reactions and play the role of regulatory elements of the immune system. We noticed similar changes when we analyzed IFN- $\gamma$ content in the secretion and the dynamics of this interferon in the process of LILT assisted treatment. The results of the carried out studies agree with the evidence on the interferon-inducing properties of LILT. As a result of the LILT assisted treatment of women with Chlamydia cervitis the concentrations of the above cytokines did not differ from those of the intact donors, while after the basic treatment these indices remained at the levels they had before treatment. Probably the main principle of LILT complex effect is the principle of one-targeted action leading to the potential sanative effect and, possibly, a longer aftereffect. On the whole, the effect of LILT on the condition of tissue immunity factors included the immune correction of the cellular elements involved in phagocytose, inflammation and regeneration.

\section{Conclusions}

It has been shown that LILT application increased the protective reactions in the lesion area due to the activated functions of neutrophils granulocytes and induced synthesis of the anti-inflammation cytokines by the cells of the inflamed area. Therefore, LILT application in the schemes of treating patients with Chlamydia cervitis leads to a clinical cure of the patients. It is related to the numerous data on a fairly high efficiency of this therapy method when treating the diseases of the urogenital tract. Treatment of Chlamydia cervicitis patients with LILT provides a simultaneous effect on all etiological factors and elements of pathogenesis and obtains the effect that is impossible when only one of the sanative factors is used.

When included into the complex Chlamydia cervitis therapy LILT could help solve the problem of non-medicated correction of immunological disorders in the system of reproductive system of tissue immunity of women infected with Chlamydia. Hence, we believe it to be proved, that LILT can be used locally in the complex therapy of Chlamydia cervitis. The study of cervical secretion neutrophils has found the fact that the content of active intracellular forms of oxygen was decreased in patients compared to healthy subjects. A low-intensity laser stimulated not only phagocytosis but also intracellular generation of active oxygen forms. Thus, a low-intensity laser eliminates dysfunction of cervical secretion neutrophils.

\section{References}

1. Sukhija-Cohen AC, Beymer MR, Engeran-Cordova W, Bolan RK. From Control to Crisis: The Resurgence of Sexually Transmitted Diseases. Sex Transm Dis. 2019 Feb;46(2):e8-e10. doi: 10.1097/ OLQ.0000000000000960.

2. Bjordal JM. Low level laser therapy (LLLT) and World Association for Laser Therapy (WALT) dosage recommendations. Photomedicine and Laser Surgery. 2012;30(2):61-2. 
3. Karu TI. Photobiology of low-power laser effects. Health Physics. 1989;56:691-704. https:// doi. org/10.1097/00004032-198905000-00015.

4. Zarakolu P, Çetik S, İnkaya AÇ, Ünal S. Comparison of immunochromatographic (IC) and real-time polymerase chain reaction (Rt-PCR) tests for screening, Neisseria gonorrhoeae, Chlamydia trachomatis, Ureaplasma spp. and Mycoplasma spp.in HIV-infected men]. Mikrobiyol. Bul. 2019 Jan;53(1):37-42. doi:10.5578/mb.67694.

5. Rupel K, Zupin L, Colliva A, Kamada A, Poropat A, Ottaviani G, et al. Photobiomodulation at Multiple Wavelengths Differentially Modulates Oxidative Stress In Vitro and In Vivo. Oxid Med Cell Longev. 2018 Nov 11; 2018:6510159. doi:10.1155/2018/6510159.

6. Park BH, Fikrig SM, Smithwick EM. Infection and nitroblue-tetrazolium reduction by neutrophils: A diagnostic acid. Lancet. 1968;7567(2):532-4.

7. Dolgushin II, Markova VA, Gizinger OA. Monitoring of the effect of low-intensity laser radiation with constant pulse generation on neutrophil granulocytes in vitro. Bull Exp Biol Med. 2010 Dec;150(2):222-4.

8. Gordon AM, Rowan RM. The nitroblue tetrazolium test. Scott Med J. 1973 Jan; 18(1):21-6. Review.

9. John M. [The NBT test - a review]. Folia Haematol Int Mag Klin Morphol Blutforsch. 1980;107(3):358-71. Review. (in German)

10. Gizinger OA, Moskvin SV, Ziganshin OR, Shemetova MA. The effect of continuous low-intensity laser irradiation of the red spectrum on the changes in the functional activity and speed of NADPH-oxidase response of human peripheral blood neutrophils Vopr Kurortol Fizioter Lech Fiz Kult. 2016; 93 (5):28-33. https://doi.org/ 10.17116/ kurort2016528-33. (in Russian)

11. Gizinger OA, Dolgushin II, Letiaeva OI. [Analysis of parameters of reproductive tract mucosal immunity in women with chlamydial infection before and after local magnetolaserotherapy]. Vopr. Kurortol. Fizioter. Lech. FizKult. 2010. Sep-Oct;(5):30-3. (in Russian) 